\title{
Continuous-wave Laser on Er,Yb-Codoped Pentaborate Crystal
}

\author{
K.N. Gorbachenya ${ }^{1}$, V.E. Kisel ${ }^{1}$, R.V. Deineka ${ }^{1}$, A.S. Yasukevich ${ }^{1}$, N.V. Kuleshov ${ }^{1}$, \\ V.V. Maltsev², D.D. Mitina ${ }^{2}$, E.A. Volkova ${ }^{2}$, N.I. Leonyuk ${ }^{2}$ \\ ${ }^{1}$ Center for Optical Materials and Technologies, Belarusian National Technical University, \\ Nezavisimosty Ave., 65, Minsk 220013, Belarus \\ ${ }^{2}$ Department of Crystallography and Crystal Chemistry, Moscow State University, \\ 119992 GSP-2 Moscow, Russia
}

Received 14.10.2019

Accepted for publication 28.11.2019

\section{Abstract}

We report, for the first time to our knowledge, a diode-pumped continuous-wave microchip Er, $\mathrm{Yb}: \mathrm{YMgB}_{5} \mathrm{O}_{10}$ laser. The purpose of this work was to study the growth technique, spectroscopic properties and continuous-wave laser performance of $\mathrm{Er}^{3+}, \mathrm{Yb}^{3+}: \mathrm{YMgB}_{5} \mathrm{O}_{10}$ novel crystal.

Absorption and luminescence spectra as well as kinetics of luminescence decay were studied. Ytterbiumerbium energy transfer efficiency was determined. The output characteristics (output power, slope efficiency, laser wavelength) of $\mathrm{Er}^{3+}, \mathrm{Yb}^{3+}: \mathrm{YMgB}_{5} \mathrm{O}_{10}$ laser were determined.

Two intensive absorption bands with peaks centered at $937 \mathrm{~nm}$ and $976 \mathrm{~nm}$ were observed in the absorption spectra at the wavelength near $1 \mu \mathrm{m}$. The maximum value of absorption cross-section was determined to be $1.5 \cdot 10^{-20} \mathrm{~cm}^{2}$ at $976 \mathrm{~nm}$ for polarization $E / / N_{g}$. A number of narrow lines were observed in the absorption spectra in the $1425-1575 \mathrm{~nm}$ spectral range (transition ${ }^{4} \mathrm{I}_{15 / 2} \rightarrow{ }^{4} \mathrm{I}_{13 / 2}$ of erbium ions). The lifetime of the upper laser level ${ }^{4} \mathrm{I}_{13 / 2}$ of $\mathrm{Er}^{3+}$ ions was determined to be $390 \pm 20 \mu \mathrm{s}$. The ytterbiumerbium energy transfer efficiency for $\mathrm{YMgB}_{5} \mathrm{O}_{10}$ crystal with 2 at.\% of $\mathrm{Er}^{3+}$ and 11 at. $\%$ for $\mathrm{Yb}^{3+}$ was close $^{3}$ to $84 \%$. The maximal continuous-wave output power of $0.2 \mathrm{~W}$ with slope efficiency of $8 \%$ regarding to absorbed pump power was realized at the wavelength of $1570 \mathrm{~nm}$. With the improvement of cavity parameters the output laser performance of the Er,Yb:YMgB $\mathrm{O}_{10}$ crystal can be further enhanced.

Taking into account high thermal conductivity of $\approx 6.2 \mathrm{~W} \cdot \mathrm{m}^{-1} \cdot \mathrm{K}^{-1}$, the Er, $\mathrm{Yb}: \mathrm{YMgB}_{5} \mathrm{O}_{10}$ crystal can be considered as a good gain medium for $1.5 \mu \mathrm{m}$ lasers for applications in laser rangefinder and LIDAR systems.

Keywords: erbium, ytterbium, borate crystals, spectroscopy, diode-pumped, continuous-wave laser operation.

DOI: $10.21122 / 2220-9506-2019-10-4-301-307$

\begin{tabular}{ll}
\hline Адрес для переписки: & Address for correspondence: \\
К.Н. Горбаченя & Gorbachenya K.N. \\
Центр оптических материалов и технологий, Белорусский & Center for Optical Materials and Technologies, Belarusian National \\
национальный технический университет, & Technical University, \\
пр-т Независимости, 65, г. Минск 220013, Беларусь & Nezavisimosty Ave., 65, Minsk 220013, Belarus \\
e-таil: gогby@bntu.by & e-mail: gorby @bntu.by \\
\hline Для цитирования: & For citation: \\
K.N. Gorbachenуa, V.E. Kisel, R.V. Deineka, A.S. Yasukevich, & K.N. Gorbachenya, V.E. Kisel, R.V. Deineka, A.S. Yasukevich, \\
N.V. Kuleshov, V.V. Maltsev, D.D. Mitina, E.A. Volkova, N.I. Leonyuk. & N.V. Kuleshov, V.V. Maltsev, D.D. Mitina, E.A. Volkova, N.I. Leonyuk. \\
Continuous-wave Laser on Er,Yb-Codoped Pentaborate Crystal. & Continuous-wave Laser on Er,Yb-Codoped Pentaborate Crystal. \\
Приборы и методы измерений. & Devices and Methods of Measurements. \\
2019. - Т. 10, № 4.- C. 301-307. & 2019, vol. 10, no. 4, pp. 301-307. \\
DОI: $10.21122 / 2220-9506-2019-10-4-301-307$ & DOI: 10.21122/2220-9506-2019-10-4-301-307 \\
\hline
\end{tabular}




\title{
УДК 621.3.038.825.2
}

\section{Непрерывный лазер на кристалле пентабората, соактивированного ионами эрбия и иттербия}

\author{
К.Н. Горбаченя ${ }^{1}$, В.Э. Кисель ${ }^{1}$, Р.В. Дейнека ${ }^{1}$, А.С. Ясюкевич ${ }^{1}$, Н.В. Кулешов ${ }^{1}$, \\ В.В. Мальцев ${ }^{2}$, Д.Д. Митина ${ }^{2}$, Е.А. Волкова ${ }^{2}$, Н.И. Леонюк ${ }^{2}$ \\ ${ }^{1}$ Центр оптических материалов и технологий, \\ Белорусский национальный технический университет, \\ пр-т Независимости, 65, Минск 220013, Беларусь \\ ${ }^{2}$ Московский государственный университет имени М.В. Ломоносова, \\ Ленинские горы, 1, Москва 119991, Россия
}

Поступила 14.10.2019

Принята к печати 28.11.2019

Впервые сообщается о непрерывном лазере на кристалле $\mathrm{Er}, \mathrm{Yb}: \mathrm{YMgB}_{5} \mathrm{O}_{10}$ с диодной накачкой. Изучены условия синтеза кристаллов, спектры поглощения и люминесценции, кинетики затухания люминесценции. Определена эффективность переноса энергии от ионов иттербия к ионам эрбия. Определены выходные характеристики (выходная мощность, дифференциальный КПД, длина волны генерации) лазера на основе кристалла $\mathrm{Er}^{3+}, \mathrm{Yb}^{3+}: \mathrm{YMgB}_{5} \mathrm{O}_{10}$.

В спектрах поглощения в области 1 мкм наблюдаются две интенсивные полосы поглощения с пиками на длинах волн 937 нм и 976 нм. Максимальное поперечное сечение поглощения достигает $1.5 \cdot 10^{-20} \mathrm{~cm}^{2}$ на длине волны 976 нм для поляризации $E / / N_{g}$. В спектре поглощения в спектральной области 1425-1575 нм наблюдается набор узких полос поглощения. Измеренное время жизни верхнего уровня ${ }^{4} \mathrm{I}_{13 / 2}$ ионов $\mathrm{Er}^{3+}$ составило $390 \pm 20$ мкс. Эффективность переноса энергии от ионов иттербия к ионам эрбия для кристалла $\operatorname{Er}\left(2\right.$ ат.\%), $\mathrm{Yb}\left(11\right.$ ат.\%): $\mathrm{YMgB}_{5} \mathrm{O}_{10}$ достигала $84 \%$. Максимальная выходная мощность лазерной генерации на длине волны 1570 нм составила 0,2 Вт при дифференциальном КПД $8 \%$.

Благодаря высокой теплопроводности $\left(\approx 6.2 \mathrm{BT} \cdot \mathrm{M}^{-1} \cdot \mathrm{K}^{-1}\right)$ кристалла $\mathrm{Er}, \mathrm{Yb}: \mathrm{YMgB}_{5} \mathrm{O}_{10}$, он может быть с успехом использован в качестве активной среды для лазеров дальномерных систем и ЛИДАРов.

Ключевые слова: эрбий, иттербий, бораты, спектроскопические исследования, диодная накачка, непрерывная лазерная генерация.

DOI: $10.21122 / 2220-9506-2019-10-4-301-307$

\footnotetext{
Адрес для переписки:

К.Н. Горбаченя

Центр оптических материалов и технологий, Белорусский

наииональный технический университет,

nр-т Независимости, 65, г. Минск 220013, Беларусь

e-mail: gorby@bntu.by

Для цитирования:

K.N. Gorbachenya, V.E. Kisel, R.V. Deineka, A.S. Yasukevich,

N.V. Kuleshov, V.V. Maltsev, D.D. Mitina, E.A. Volkova, N.I. Leonyuk

Continuous-wave Laser on Er,Yb-Codoped Pentaborate Crystal.

Приборы и методы измерений.

2019. - Т. 10, № 4. - С. 301-307.

DOI: $10.21122 / 2220-9506-2019-10-4-301-307$
}

\author{
Address for correspondence: \\ K.N. Gorbachenya \\ Center for Optical Materials and Technologies, Belarusian National \\ Technical University, \\ Nezavisimosty Ave., 65, Minsk 220013, Belarus \\ e-mail:gorby@bntu.by \\ For citation: \\ K.N. Gorbachenya, V.E. Kisel, R.V. Deineka, A.S. Yasukevich, \\ N.V. Kuleshov, V.V. Maltsev, D.D. Mitina, E.A. Volkova, N.I. Leonyuk. \\ Continuous-wave Laser on Er,Yb-Codoped Pentaborate Crystal. \\ Devices and Methods of Measurements. \\ 2019, vol. 10, no. 4, pp. 301-307. \\ DOI: $10.21122 / 2220-9506-2019-10-4-301-307$
}




\section{Introduction}

Nowadays eye-safe lasers emitting in 1.5$1.6 \mu \mathrm{m}$ spectral range find application in LIDAR systems for robots, self-driving cars, etc. due to its eye-safety and high transparency of the atmosphere. Currently, many sources are emitting in this spectral range, but solid-state lasers on $\mathrm{Er}^{3+}$ and $\mathrm{Yb}^{3+}$ codoped crystals are of greatest interest. Phosphate glasses currently are the leading $\mathrm{Er}^{3+}, \mathrm{Yb}^{3+}$-codoped laser materials, because they combine very efficient energy transfer from $\mathrm{Yb}^{3+}$ to $\mathrm{Er}^{3+}$ ions $(\eta \approx 90 \%)$ with a long lifetime of the erbium upper laser level ${ }^{4} \mathrm{I}_{13 / 2}(7-8 \mathrm{~ms})$ and short lifetime of the ${ }^{4} \mathrm{I}_{11 / 2}$ energy level $(2-3 \mu \mathrm{s})$, which prevents the depopulation of this level because of excited-state absorption and upconversion processes [1]. However, phosphate glass has poor thermomechanical properties (a thermal conductivity of $0.85 \mathrm{~W} \cdot \mathrm{m}^{-1} \cdot \mathrm{K}^{-1}$ ) [2], which limits the average output power of Er,Yb:glass lasers because of the thermal effects. A maximal continuous-wave (CW) output power did not exceed $353 \mathrm{~mW}$ with a slope efficiency of $26 \%$ [3]. For this reason, the search for new crystalline hosts for $\mathrm{Er}, \mathrm{Yb}$-codoping is ongoing.

Due to their spectroscopic characteristics and high thermal conductivity, Er,Yb-codoped borate crystals are most widely used crystalline laser media for lasers operating in the 1.5-1.6 $\mu \mathrm{m}$ spectral range. To date, effective laser operation has been obtained by using various erbium, ytterbium codoped borate crystals [4-9]. By using of Er, $\mathrm{Yb}: \mathrm{GdAl}_{3}\left(\mathrm{BO}_{3}\right)_{4}$ crystal the maximal output power in continuouswave mode exceeded $1.5 \mathrm{~W}$ with the slope efficiency of about $35 \%$ [9]. Recently, one more borate crystal $\mathrm{YMgB}_{5} \mathrm{O}_{10}$ (YMBO) has been regarded as a potential laser host material owing to large thermal conductivity $\left(6.2 \pm 0.3 \mathrm{~W} \cdot \mathrm{m}^{-1} \cdot \mathrm{K}^{-1}\right)$ and good optical properties [10]. Moreover, in comparison with huntitetype borates, YMBO bulk crystals of large enough with good optical quality can be obtained reproducibly by optimizing the crystal growth conditions.

In this paper the laser related spectroscopy and, for the first time to our knowledge, continuous-wave laser performance of $\mathrm{Er}, \mathrm{Yb}: \mathrm{YMgB}_{5} \mathrm{O}_{10}$ crystal are presented.

\section{Experimental details}

\section{Crystal growth}

$\mathrm{Er}, \mathrm{Yb}: \mathrm{YMBO}(\mathrm{Er}=2.0$ at.\%, $\mathrm{Yb}=11$ at.\%) single crystals were obtained by high-temperature solution growth on dipped seeds (SGDS) from $\mathrm{K}_{2} \mathrm{Mo}_{3} \mathrm{O}_{10}$ flux melt. The ratio of the raw materials was $\mathrm{Er}, \mathrm{Yb}: \mathrm{YMgB}_{5} \mathrm{O}_{10}: \mathrm{K}_{2} \mathrm{Mo}_{3} \mathrm{O}_{10}=80: 20$ wt.\%. The growth technique follows Ref. [10]. The chemicals used (at least $99.996 \%$ and $99.99 \%$ purity for rare earth and other materials, respectively) were $\mathrm{R}_{2} \mathrm{O}_{3}(\mathrm{R}=\mathrm{Y}, \mathrm{Yb}, \mathrm{Er}), \mathrm{MgO}$ and $\mathrm{B}_{2} \mathrm{O}_{3}$, but $\mathrm{K}_{2} \mathrm{Mo}_{3} \mathrm{O}_{10}$ was previously sintered from $\mathrm{K}_{2} \mathrm{MoO}_{4}(99.0 \%)$ and $\mathrm{H}_{2} \mathrm{MoO}_{4}(99.5 \%)$ at $650{ }^{\circ} \mathrm{C}$ for $24 \mathrm{~h}$ by a scheme:

$\mathrm{K}_{2} \mathrm{MoO}_{4}+2 \mathrm{H}_{2} \mathrm{MoO}_{4} \rightarrow \mathrm{K}_{2} \mathrm{Mo}_{3} \mathrm{O}_{10}+2 \mathrm{H}_{2} \mathrm{O} \uparrow$.

The starting charge was placed into a platinum crucible of $250 \mathrm{ml}$ in volume and heated to a maximum temperature which is normally 100 $150{ }^{\circ} \mathrm{C}$ above the expected saturation point. After the solution homogenization within 10-20 hours, the saturation temperature $\left(T_{\text {sat }}\right)$ was accurately determined by dipping a trial YMBO crystal in the solution, and it was kept at constant temperature by observing growth/dissolution of the crystal face at different temperatures. The $T_{\text {sat }}$ were found from the experimental data on changes both in weight and micro-relief of the probe seeds after soaking in fluxed melts from $10 \mathrm{~min}$ to several hours, depending on an expected deviation from their equilibrium state. The obtained value of $T_{\text {sat }}$ was about $\approx 950{ }^{\circ} \mathrm{C}$ for the solute concentration being investigated. As a result visually macrodefectfree Er,Yb:YMBO single crystal was grown. The dimensions of the crystal obtained were typically $20 \times 15 \times 10 \mathrm{~mm}$ (Figure 1 ).

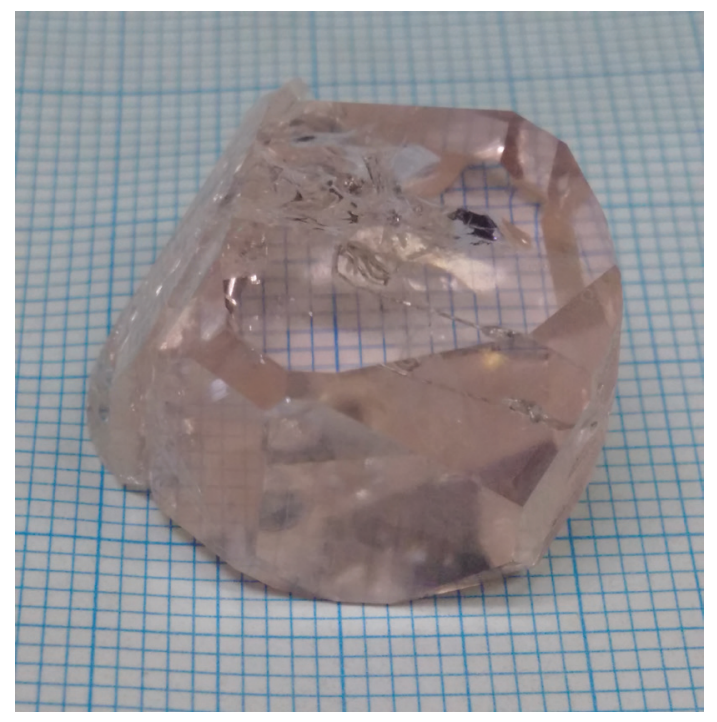

Figure 1 - The Er,Yb:YMBO crystal grown by the SGDS method 


\section{Investigation of spectroscopic characteristics}

In our study polarized absorption spectra of $\mathrm{Er}, \mathrm{Yb}: \mathrm{YMBO}$ crystal at room temperature were registered by a Varian CARY-5000 spectrophotometer in the spectral ranges $875-1025 \mathrm{~nm}$ and $1425-1575 \mathrm{~nm}$. The spectral bandwidth was $0.5 \mathrm{~nm}$. Two polished plates with dimensions of $5 \times 7 \times 2 \mathrm{~mm}^{3}$ oriented along three principal optical indicatrix axes $N_{g}, N_{m}$ and $N_{p}$ were used. The concentration of doping ions in the crystal was determined by means of a Tescan VEGA II LMU scanning electron microscope with Oxford INCA Energy 350 energy dispersive x-ray analyzer to be $1.4 \cdot 10^{20} \mathrm{~cm}^{-3}$ of $\mathrm{Er}^{3+}$ and $9.8 \cdot 10^{20} \mathrm{~cm}^{-3} \mathrm{Yb}^{3+}$.

The lifetime measurements were performed using an optical parametric oscillator based on a $\beta-\mathrm{Ba}_{2} \mathrm{~B}_{2} \mathrm{O}_{4}$ crystal and pumped by the third harmonic of a Q-switched Nd:YAG laser. The fluorescence from the sample was collected on the entrance slit of a monochromator and registered by an InGaAs photodiode coupled with a $500 \mathrm{MHz}$ digital oscilloscope. It is well known that radiation trapping strongly influences the fluorescence dynamics of ytterbium ions because of the significant overlap of the absorption and emission bands. To prevent reabsorption the measurements of $\mathrm{Yb}^{3+}$ luminescence kinetics were performed using a fine powder of the crystals immersed in glycerin [11].

The energy transfer efficiency was determined by estimation of the ${ }^{2} \mathrm{~F}_{5 / 2}$ level lifetime shortening in Er, $\mathrm{Yb}$-codoped crystals and $\mathrm{Yb}$-single doped crystal according to the formula (2) [12]:

$\eta=\tau\left(1 / \tau-1 / \tau_{0}\right)$,

where $\tau$ is the ytterbium ${ }^{2} \mathrm{~F}_{5 / 2}$ level lifetime in Er, $\mathrm{Yb}$ codoped crystal; $\tau_{0}$ is the ytterbium ${ }^{2} \mathrm{~F}_{5 / 2}$ level lifetime in $\mathrm{Yb}$ single-doped crystal.

Luminescence spectra were registered at room temperature using an experimental setup that ensured synchronous detection of the optical signal. The excitation source was a semiconductor laser diode emitting at the wavelength near $976 \mathrm{~nm}$. The luminescence was detected by an InGaAs photodetector. Its signal was processed by a lock-in amplifier. The output signal of the amplifier was digitized using an analog-to-digital converter and stored on a computer.

\section{Setup for continuous-wave laser experiments}

A plane-plane $N_{p}$-cut Er,Yb:YMBO crystal with a length of $2 \mathrm{~mm}$ was used as an active medium. The polished facets of the crystal were antireflectioncoated for both pump (900-1100 nm) and laser $(1500-1650 \mathrm{~nm})$ wavelengths. The active element was wrapped in indium foil for good thermal contact and mounted between two copper slabs with the hole in the center to permit passing of pump and laser beams. The temperature of an active element was kept at $20^{\circ} \mathrm{C}$. As a pump source a $976 \mathrm{~nm}$ fiber coupled laser diode $(\varnothing 105 \mu \mathrm{m}, \mathrm{NA}=0.22)$ was used. The plano-plano cavity with geometrical cavity length not exceeding $5 \mathrm{~mm}$ was adopted. The onelens focusing system focused the pump beam into a $120-\mu \mathrm{m}$ spot inside the laser crystal with the confocal parameter of $2.3 \mathrm{~mm}$. Three output couplers with different transmittances at the laser wavelengths were used during laser experiments. The laser setup is shown in Figure 2.

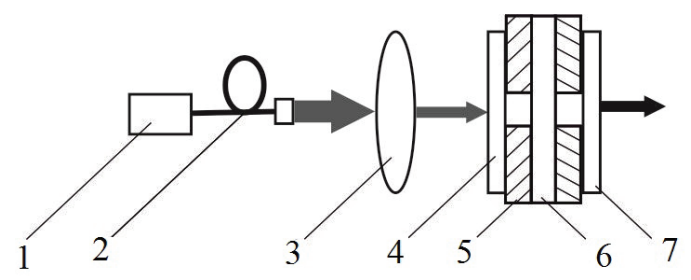

Figure 2 - The experimental setup of a continuous wave diode-pumped Er,Yb:YMBO laser: 1-laser diode; 2 - fiber; 3 - focusing system; 4 - input mirror; 5 - copper heatsink; 6 - active element; 7 - output coupler

\section{Results and discussion}

\section{Spectroscopy}

The room-temperature polarized absorption cross-section spectra of the Er,Yb:YMBO crystal in the spectral range of $875-1025 \mathrm{~nm}$ (transitions of ${ }^{2} \mathrm{~F}_{7 / 2} \rightarrow{ }^{2} \mathrm{~F}_{5 / 2}$ of $\mathrm{Yb}^{3+}$ ions and ${ }^{4} \mathrm{I}_{15 / 2} \rightarrow{ }^{4} \mathrm{I}_{11 / 2}$ of $\mathrm{Er}^{3+}$ ions) are shown in Figure 3. Two intensive absorption lines with peaks centered at $937 \mathrm{~nm}$ and $976 \mathrm{~nm}$ are observed. These peaks coincide with the emission wavelengths of commercial available InGaAs laser diodes. The maximum value of absorption cross-section was determined to be $1.5 \cdot 10^{-20} \mathrm{~cm}^{2}$ at $976 \mathrm{~nm}$ with the bandwidth (FWHM) of about $3.5 \mathrm{~nm}$ for polarization $E / / N_{g}$ axis. Thus, the pump beam polarization corresponded to the $N_{g}$ axis of the crystal will be preferable for laser experiments.

Figure 4 shows the room-temperature polarized absorption spectra of Er,Yb:YMBO crystal in the 1425-1575 nm spectralrange(transition ${ }^{4} \mathrm{I}_{15 / 2} \rightarrow{ }^{4} \mathrm{I}_{13 / 2}$ of erbium ions). A number of narrow lines are observed for three polarizations. The maximum value of absorption cross-section was determined to be $1.6 \cdot 10^{-20} \mathrm{~cm}^{2}$ at $1482 \mathrm{~nm}$ for polarization $E / / N_{m}$ axis. 


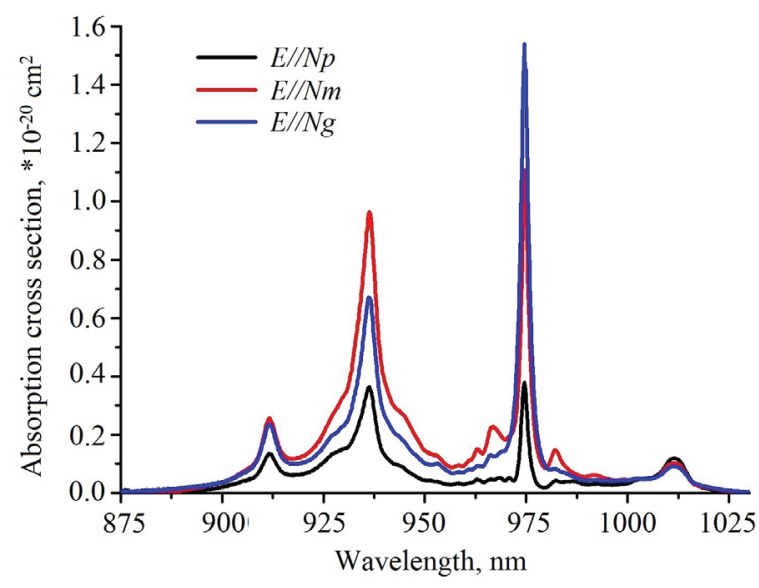

Figure 3 - Polarised absorption cross-section spectra of $\mathrm{Er}, \mathrm{Yb}: \mathrm{YMBO}$ crystal at near $1 \mu \mathrm{m}$

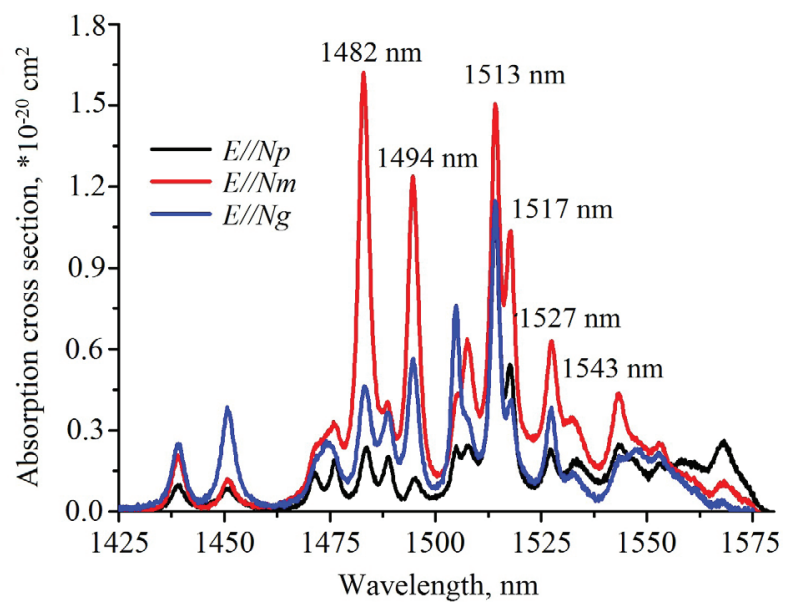

Figure 4 - Polarised absorption cross-section spectra of Er,Yb:YMBO crystal at near $1.5 \mu \mathrm{m}$

The measured decay curve of $1.5 \mu \mathrm{m}$ emission was single exponential (Figure 5), and the luminescence decay time of the ${ }^{4} \mathrm{I}_{13 / 2}$ level was obtained to be about $390 \pm 20 \mu \mathrm{s}$.

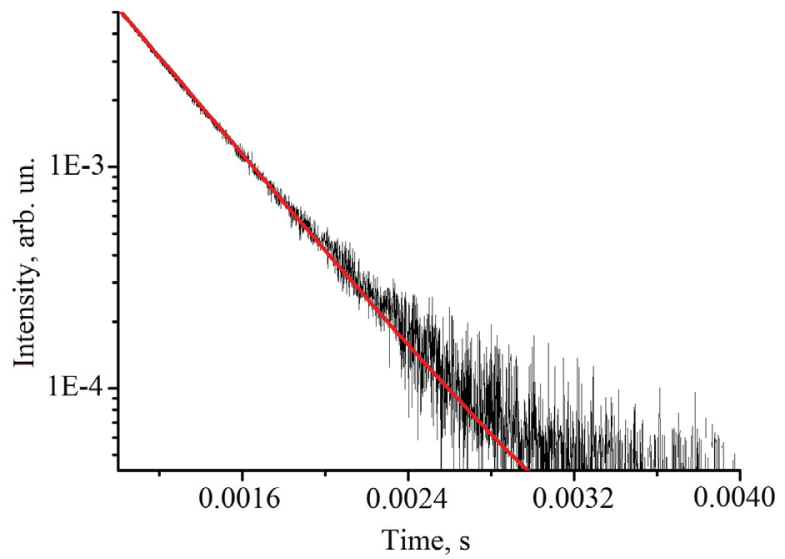

Figure 5-Kinetics of luminescence decay of $\mathrm{Er}, \mathrm{Yb}: \mathrm{YMBO}$ in the region of about $1.5 \mu \mathrm{m}$
The dependence of obtained lifetimes of ${ }^{2} \mathrm{~F}_{5 / 2}$ energy level on different weight content of $\mathrm{Yb}(1$ at.\%):YMBO crystalline powders in glycerin suspension is presented in Figure 6. The fluorescence lifetime decreased with the decreasing of powder concentration in suspension. Starting from a certain powder content, the lifetime remained constant despite further dilution, which indicates negligible reabsorption influence. The ${ }^{2} \mathrm{~F}_{5 / 2}$ energy level lifetime of ytterbium ions was measured to be $580 \pm 10 \mu \mathrm{s}$.

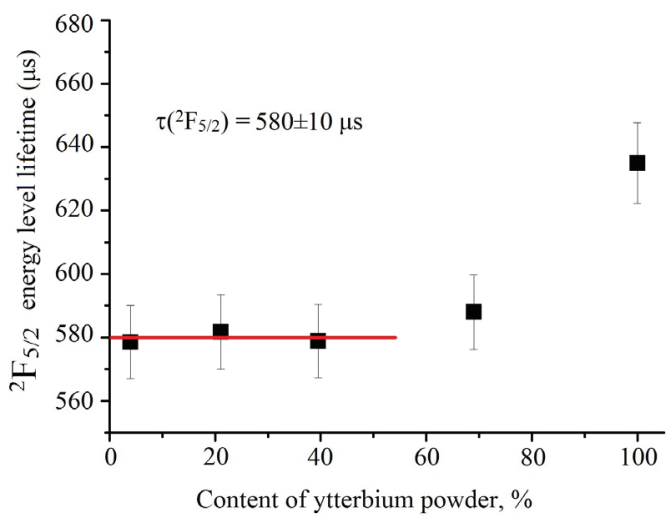

Figure 6 - The ${ }^{2} \mathrm{~F}_{5 / 2}$ energy level lifetimes of $\mathrm{Yb}(1$ at.\%):YMBO crystal

The ${ }^{2} \mathrm{~F}_{5 / 2}$ energy level lifetime of $\mathrm{Yb}^{3+}$ was measured to be $95 \pm 5 \mu$ s in $\operatorname{Er}(2$ at.\%), $Y b(11$ at.\%):YMBO. By using formula (2) the energy transfer efficiency from ytterbium to erbium ions was calculated to be about $84 \%$. It should be mentioned that the energy transfer efficiency in Er,Yb:YMBO is similar to those in $\mathrm{Er}, \mathrm{Yb}: \mathrm{YAB}$ and $\mathrm{Er}, \mathrm{Yb}: \mathrm{GdAB}$ crystals $[8,9]$.

The polarised luminescence spectra of the Er,Yb:YMBO crystal (Figure 7) measured at room temperature are characterized by a structured bands in the spectral range $1450-1650 \mathrm{~nm}$.

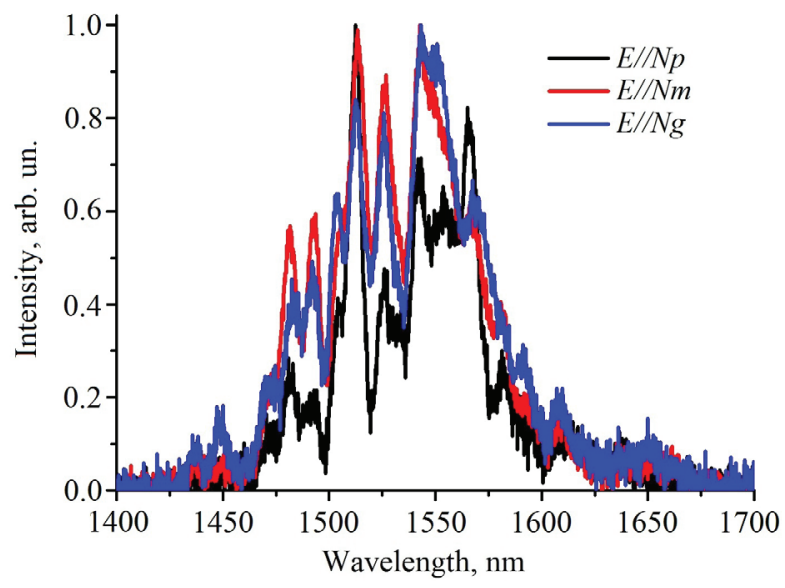

Figure 7-Polarised luminescence spectrum of the Er,Yb:YMBO crystal 


\section{Laser characteristics of $\mathrm{Er}, \mathrm{Yb}: \mathrm{YMBO}$ crystal}

Input-output characteristics of continuouswave diode-pumped microchip Er,Yb:YMBO laser are plotted in Figure 8. The best laser performance was demonstrated with the $2 \%$ output coupler transmittance. The laser threshold was measured to be about $2 \mathrm{~W}$ of absorbed pump power. The maximum CW output power of $200 \mathrm{~mW}$ with the slope efficiency near $8 \%$ was obtained at $1570 \mathrm{~nm}$ at about $4.7 \mathrm{~W}$ of absorbed pump power. After further increasing of pump power, the rising of output laser power wasn't observed. It provides evidence for the influence of thermal load in the crystal on laser performance. To our mind, with the improvement of cavity parameters the output laser performance of the $\mathrm{Er}, \mathrm{Yb}: \mathrm{YMgB}_{5} \mathrm{O}_{10}$ crystal can be further enhanced.

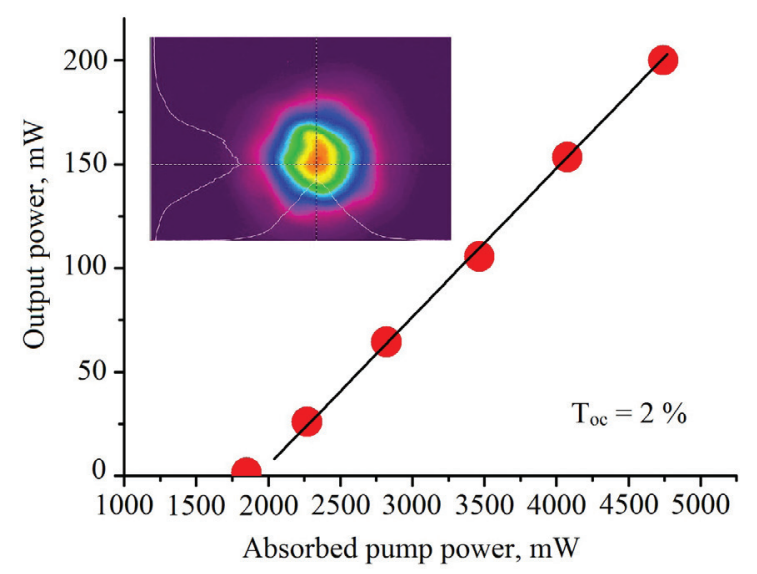

Figure 8-The laser performance of Er,Yb:YMBO crystal in continuous-wave mode

The laser radiation was linearly polarized $\left(E / / N_{m}\right)$. The laser wavelength was measured to be $1570 \mathrm{~nm}$. The spatial profile of the output beam measured at $4.5 \mathrm{~W}$ of absorbed pump power is presented in the inset in Figure 8.

\section{Conclusion}

In conclusion, a continuous-wave diodepumped Er,Yb:YMBO laser with output power of $200 \mathrm{~mW}$ and slope efficiency of $8 \%$ at near $1570 \mathrm{~nm}$ was realized for the first time to our knowledge. Absorption and luminescence spectra, emission lifetimes, and efficiencies of energy transfer from $\mathrm{Yb}^{3+}$ to $\mathrm{Er}^{3+}$ ions were determined.

\section{Acknowledgments}

This research was supported by Russian Science Foundation grant (project No. 19-12-00235).

\section{References}

1. Karlsson G., Laurell F., Tellefsen J., Denker B., Galagan B., Osiko V., Sverchkov S. Development and characterization of $\mathrm{Yb}-\mathrm{Er}$ laser glass for high average power laser diode pumping. Appl. Phys. B., 2002, vol. 75, no. 1 , pp. 41-46. DOI: $10.1007 / \mathrm{s} 00340-002-0950-4$

2. Taccheo S., Sorbello G., Laporta P., Karlsson G., Laurell F. 230-mW diode-pumped single-frequency Er, $\mathrm{Yb}$ laser at $1.5 \mu \mathrm{m}$. IEEE Photonics Technology Letters, 2001, vol. 13, no. 1, pp. 19-21. DOI: 10.1109/68.903207

3. Danger T., Huber G., Denker B.I., Galagan B.I., Sverchkov S.E. Diode-pumped cw laser around $1.54 \mu \mathrm{m}$ using $\mathrm{Yb}$, Er-doped silico-boro-phosphat glass in Conference on Lasers and Electro-Optics, D. Scifres and A. Weiner, eds., Optical Society of America, 1998, paper CTuM71.

4. Burns P., Dawes J., Dekker P., Pipper J., Jiang H., Wang J. Optimization of Er,Yb:YCOB for $\mathrm{cw}$ laser operation. IEEE J. Quantum Electron., 2004, vol. 40, no. 11, pp. 1575-1582. DOI: 10.1109/JQE.2004.834935

5. Huang J., Chen Y., Lin Y., Gong X., Luo Z., Huang Y. High efficient $1.56 \mu \mathrm{m}$ laser operation of Czochralski grown Er, $\mathrm{Yb}: \mathrm{Sr}_{3} \mathrm{Y}_{2}\left(\mathrm{BO}_{3}\right)_{4}$ crystal. Optics Express, 2008, vol. 16, no. 22, pp. 17243-17248.

DOI: $10.1364 / \mathrm{OE} .16 .017243$

6. Chen Y., Lin Y., Huang J., Gong X., Luo Z., Huang Y. Enhanced performances of diode-pumped sapphire $\mathrm{Er}^{3+}: \mathrm{Yb}^{3+}: \mathrm{LuAl}_{3}\left(\mathrm{BO}_{3}\right)_{4}$ sapphire microlaser at

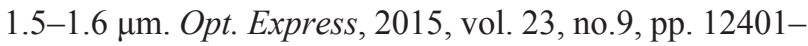
12406. DOI: $10.1364 /$ OE.23.012401

7. Gorbachenya K.N., Deineka R.V., Kisel V.E., Yasukevich A.S., Shekhovtsov A.N., Kosmyna M.B., Kuleshov N.V. Er, Yb:Ca $\mathrm{RE}_{2}\left(\mathrm{BO}_{3}\right)_{4} \quad(\mathrm{RE}=\mathrm{Y}, \mathrm{Gd}) \quad-$ Novel $1.5 \mu \mathrm{m}$ Laser Crystals. Devices and Methods of Measurements, 2019, vol. 10, no. 1, pp. 14-22.

DOI: $10.21122 / 2220-9506-2019-10-1-14-22$

8. Kisel V.E., Gorbachenya K.N., Yasukevich A.S., Ivashko A.M., Kuleshov N.V., $\quad$ Maltsev V.V., Leonyuk N.I. Passively Q-switched microchip Er, $\mathrm{Yb}: \mathrm{YAl}_{3}\left(\mathrm{BO}_{3}\right)_{4}$ diode-pumped laser. Opt. Lett., 2012, vol. 37 , no. 13 , pp. $2745-2747$.

DOI: $10.1364 /$ OL .37 .002745

9. Gorbachenya K.N., Kisel V.E., Yasukevich A.S., Maltsev V.V., Leonyuk N.I., Kuleshov N.V. Eye-safe $1.55 \mu \mathrm{m}$ passively Q-switched Er, $\mathrm{Yb}: \mathrm{GdAl}_{3}\left(\mathrm{BO}_{3}\right)_{4}$ diodepumped laser. Opt. Lett., 2016, vol. 41, no. 5, pp. 918 921. DOI: $10.1364 /$ OL.41.000918

10. Mitina D.D., Maltsev V.V., Leonyuk N.I., Gorbachenya K.N., Deineka R.V., Kisel V.E., Yasukevich A.S., Kuleshov N.V. Growth and characterization of $\mathrm{RMgB}_{5} \mathrm{O}_{10}(\mathrm{R}=\mathrm{Y}, \mathrm{La}, \mathrm{Gd})$ crystals. Inorg.Mater., 2020, vol. 56, no. 2 (accepted).

DOI: $10.1134 / \mathrm{S} 0002337 \mathrm{X} 2002013 \mathrm{X}$ 
11. Sumida D.S., Fan T.Y. Effect of radiation trapping on fluorescence lifetime and emission cross section measurements in solid-state laser media. Opt. Lett., 1994, vol. 19, no. 17, pp. 343-1345.

DOI: $10.1364 /$ OL. 19.001343

12. Denker B., Galagan B., Ivleva L., Osiko V.,
Sverchkov S., Voronina I., Hellstrom J.E., Karlsson G., Laurell $\mathrm{F}$. Luminescent and laser properties of $\mathrm{Yb}, \mathrm{Er}$ activated $\mathrm{GdCa}_{4} \mathrm{O}\left(\mathrm{BO}_{3}\right)_{3}$ - a new crystal for eyesafe 1.5 micrometer lasers. Appl. Phys. B., 2004, vol. 79, no. 5, pp. 577-581.

DOI: $10.1007 / \mathrm{s} 00340-004-1605-4$ 